\title{
Quality and shelf life of noodles containing onion powder
}

\author{
Yo Sep Kim, Na Young Park, Hong Kyoon No* \\ Department of Food Science and Technology, Catholic University of Daegu, Gyeongsan 38430, Korea
}

\section{양파분말을 첨가한 국수의 품질과 저장성}

\author{
김요셉 · 박나영 · 노홍균* \\ 대구가톨릭대학교 식품공학전공
}

\begin{abstract}
The quality and shelf life of noodles containing onion powder $(0,3,5$, and $10 \%)$ were investigated. The $\mathrm{pH}$ of raw noodles decreased by increasing the concentration of onion power. The weight, volume, and water absorption of the cooked noodles were comparable, irrespective of onion powder concentrations. Color $L$ and a values of raw noodles decreased, while b value increased by addition of onion powder. However, no considerable differences in color values were observed among the control and onion noodle groups after cooking $(\mathbf{p}<\mathbf{0 . 0 5})$. The total polyphenol contents and DPPH radical scavenging activities of raw and cooked noodles increased with increasing onion powder concentrations, although the latter had lower values. In the aspect of texture, the control group showed higher hardness and chewness than those of noodle containing onion powder, except for springiness. The results of raw noodle storage at $10^{\circ} \mathrm{C}$ for 12 days indicated that raw onion noodles, especially those with $5 \%$ onion powder added, could be preserved for at least 6 days longer than the control noodle. In the sensory evaluation of cooked noodles, no significant differences in appearance, taste, flavor, texture and overall acceptability were observed between the control and onion noodle groups. This study indicates that the addition of $5 \%$ onion powder could improve the functionality and shelf life of noodles.
\end{abstract}

Key words : quality characteristics, sensory evaluation, shelf life, noodle, onion powder

\section{서 론}

최근 급속한 식품산업의 발달로 인하여 식생활 형식이 바뀌어감에 따라 식품에서 면류의 이용이 높은 비중을 차지 하게 되었다. 생면은 밀가루 반죽을 압연한 후 절단하여 생산하는 절단면으로, 칼국수가 우리나라의 대표적인 생면 제품이다(1). 그러나 생면은 수분함량이 높은 상태에서 유 통되기 때문에 유통과정 중 곰팡이, 효모와 세균의 증식에 의해 쉽게 변질되는 단점이 있어(2) 생면의 소비를 증대시 키기 위해서는 저장성을 향상시킬 수 있는 방법의 개발이

*Corresponding author. E-mail : hkno@cu.ac.kr Phone : 82-53-850-3219, Fax : 82-53-850-3219

Received 12 January 2016; Revised 18 February 2016; Accepted 29 February 2016.

Copyright (c) The Korean Society of Food Preservation. All rights reserved.
요구된다. 또한 최근에는 건강식품 및 성인병 예방 식품 등에 대한 관심도가 증가하고 있어 다양한 생리활성 및 기능성을 가진 국수의 개발이 요구된다.

양파(Allium cepa L.)는 백합과 파속 식물로 오래전부터 특유한 맛과 향 때문에 마늘과 함께 우리나라의 대표적인 향신료로 사용되어 왔다(3). 양파에는 황함유 화합물과 quercetin 등의 flavonoid 물질이 다량 함유되어 있어( 3,4$)$ 항산화 효과(5), 항균 효과, 혈중 콜레스테롤 감소(6) 등에 효과가 있는 것으로 보고되고 있다. 지금까지 양파를 국수 에 이용한 연구로는 양파분말 첨가 국수의 품질 특성(3), 양파즙을 첨가하여 만든 밀가루의 반죽과 국수의 특성(7) 및 양파즙 첨가 생면의 최적화(8) 등이 보고되고 있어 양파 분말을 첨가한 생면류에 대한 연구는 매우 미비한 실정이다.

본 연구에서는 기능성 부여와 저장성이 증진된 국수를 개발하고자 항산화성과 항균성을 지닌 양파분말을 생면에 첨가하여 품질 특성과 저장성 등을 검토하고자 하였다. 


\section{재료 및 방법}

\section{실험 재료}

본 실험에 사용한 양파는 경북 경산시 하양읍 인근의 대형마트에서 구입하여 껍질을 벗기고 가식부를 절단하여 동결건조(Labconco Co., Kansas, MI, USA)시킨 후 믹서기 (SMX-G303, Shinil Co., Gyeonggi-do, Korea)로 분쇄하여 분말로 사용하였다. 국수 제조에 사용된 밀가루는 시판 1 등 급 중력분(Daehan Flour Mills Co., Incheon, Korea)을 사용 하였고, 소금은 천일염(CheilJedang, Busan, Korea), 실험용 수는 증류수를 사용하였다.

\section{양파 생면의 제조}

양파분말을 첨가한 생면(양파 생면으로 칭함)의 제조는 Park 등(9)의 방법을 참고하여 Table 1과 같은 배합비로 제조하였다. 즉, 밀가루 사용량의 $0 \%$ (대조구), $3 \%, 5 \%$ 및 $10 \%$ 를 각 양파분말로 대체하여 복합분을 제조하였으며, 전체 복합분 중량의 $2 \%$ 에 해당하는 소금을 물 $(45 \mathrm{~mL})$ 에 첨가하여 면을 제조하였다. 자동 반죽기(KMC570, De'LonghiKenwood Appliances Co., Dongguan, China)에서 10분간 반 죽한 다음 polyethylene백에 넣고 밀봉하여 상온에서 1시간 숙성시켰다. 숙성된 반죽은 제면기(Shule Pasta Machine QM-17, Changzhou, China)에서 롤 간격을 $2 \mathrm{~mm}$ 로 2회 sheeting하여 면대를 형성한 후 면의 두께는 $2 \mathrm{~mm}$, 너비 는 $6 \mathrm{~mm}$, 길이는 $25 \mathrm{~cm}$ 로 국수를 제조한 후 시료로 사용 하였다.

Table 1. Formula for preparation of raw noodles containing onion powder

\begin{tabular}{ccccc}
\hline \multirow{2}{*}{ Material } & \multicolumn{4}{c}{ Noodle $^{1)}$} \\
\cline { 2 - 5 } & OP0 & OP3 & OP5 & OP10 \\
\hline Wheat flour (g) & 100 & 97 & 95 & 90 \\
Onion powder (g) & 0 & 3 & 5 & 10 \\
Salt (g) & 2 & 2 & 2 & 2 \\
Water (mL) & 45 & 45 & 45 & 45 \\
\hline
\end{tabular}

${ }^{1)} \mathrm{OP} 0$ (control), noodle added with $0 \%$ onion powder; OP3, noodle added with $3 \%$ onion powder; OP5, noodle added with $5 \%$ onion powder; OP10, noodle added with $10 \%$ onion powder.

\section{양파 생면의 수분함량과 $\mathrm{pH}$ 측정}

양파 생면의 수분함량은 적외선 수분측정기(MB45 Moisture analyzer, Ohaus Co., Pine Brook, NJ, USA)를 사용하여 측정 하였다. $\mathrm{pH}$ 측정은 $\mathrm{Kim}$ 과 $\operatorname{Jung}(10)$ 의 방법에 따라 생면 $10 \mathrm{~g}$ 에 증류수 $40 \mathrm{~mL}$ 를 첨가하여 마쇄기(Matsushita Electric Ind., Kadoma, Japan)로 2 분간 마쇄한 후 $\mathrm{pH}$ meter(Model 720p, istek Inc., Seoul, Korea)로 측정하였다.

\section{양파 생면의 조리특성}

양파 생면의 조리특성은 $\mathrm{Kim}$ 과 $\mathrm{Jung}(10)$ 의 방법에 준하 여 생면 $50 \mathrm{~g}$ 을 $500 \mathrm{~mL}$ 의 끓는 증류수에 넣고 3분간 조리한 다음 체에 받쳐 흐르는 물에 10 초간 헹구고 5 분간 방치한 후 조리면의 중량, 부피, 수분흡수율 및 국물의 탁도를 측정 하였다. 조리면의 중량은 저울(ED3202S-CW, Sartorius AG, Goettingen, Germany)로 측정하였으며, 부피는 중량을 측정 한 후 $300 \mathrm{~mL}$ 의 물을 채운 메스실린더 $(500 \mathrm{~mL})$ 에 조리면을 넣어 증가하는 물의 부피로 계산하였다. 조리면의 수분 흡 수율은 조리면의 중량에서 생면의 중량을 빼고 다시 생면의 중량으로 나눈 값에 100 을 곱하여 구하였다.

$$
\text { 수분흡수율 }(\%)=\frac{\text { 조리면의 중량-생면의 중량 }}{\text { 생면의 중량 }} \times 100
$$

조리면 국물의 탁도는 조리면을 건져낸 물을 상온에서 냉각한 후 spectrophotometer(Optizen 3220UV; Mecasys Co., Daejeon, Korea)를 사용하여 $675 \mathrm{~nm}$ 에서 흡광도를 측정하 였다.

\section{양파 생면과 조리면의 색 측정}

양파 생면과 조리면의 색은 색차계(Minolta chroma meter CR-200, Minolta Camera Co., Osaka, Japan)를 이용하여 L (명도), $\mathrm{a}$ (적색도), $\mathrm{b}$ (황색도) 값을 측정하였다.

\section{양파 생면과 조리면의 총 폴리페놀 함량과 DPPH radical} 소거능 측정

국수(생면 또는 조리면) $10 \mathrm{~g}$ 에 $70 \%$ ethanol $40 \mathrm{~mL}$ 를 가하고 마쇄기로 2 분간 마쇄한 후 $2,000 \mathrm{rpm}$ 에서 20 분간 원심분리하여 얻은 상등액을 시료로 사용하였다. 총 폴리 페놀 함량은 Folin-Denis(11)의 방법에 따라 시료액 $1 \mathrm{~mL}$ 에 $0.2 \mathrm{~N}$ Folin-ciocalteau's phenol reagent $1 \mathrm{~mL}$ 를 가하여 실온 에서 3 분간 반응시키고 $7.5 \% \mathrm{Na}_{2} \mathrm{CO}_{3} 1 \mathrm{~mL}$ 를 가한 다음 암소에서 1 시간 동안 방치한 후 분광광도계(Optizen 3220UV; Mecasys Co., Daejeon, Korea)를 사용하여 $765 \mathrm{~nm}$ 에서 흡광도를 측정하였다. 총 폴리페놀 함량은 gallic acid 를 표준물질로 한 표준곡선에 의하여 산출하였다.

$\mathrm{DPPH}$ radical 소거능 측정은 Blois(12)의 방법을 변형하 여, 상기 시료액 $0.4 \mathrm{~mL}$ 에 $0.4 \mathrm{mM} \mathrm{DPPH}$ 에탄올 용액 3 $\mathrm{mL}$ 을 진탕 혼합하고, 10 분간 방치한 후 분광광도계를 사용 하여 $517 \mathrm{~nm}$ 에서 흡광도를 측정하여 아래 계산식에 준하여 계산하였다.

DPPH radical scavenging activity(\%)

$$
=\left(1-\frac{\text { 시료첨가구의 흡광도 }}{\text { 대조구의 흡광도 }}\right) \times 100
$$




\section{양파 조리면의 조직감 측정}

양파 조리면의 조직감 측정은 $\mathrm{Kim}$ 과 $\operatorname{Jung}(10)$ 의 방법을 참고로 하여 rheometer (COMPAC-100П, SUN Scientific. Co., Japan)를 이용하여 다음과 같은 조건으로 10 회 반복 측정하였다: test type mastication, adaptor type circle, adaptor diameter $15 \mathrm{~mm}$, table speed $60 \mathrm{~mm} / \mathrm{min}$, compression $60 \%$, load cell(max) $2 \mathrm{~kg}$.

\section{양파 생면의 저장성 실험}

양파 생면의 저장성 실험은 Park 등(13)의 방법을 일부 변형하여 실행하였다. 즉, 생면 $100 \mathrm{~g}$ 을 스티로폼 접시(가로 $13.5 \mathrm{~cm}$, 세로 $13.5 \mathrm{~cm}$, 높이 $2.8 \mathrm{~cm}$; Taeyang Co., Iksan, Korea)에 담고 지퍼백 $(18 \mathrm{~cm} \times 20 \mathrm{~cm}$ clean zipper bag, Cleanwrap Co., Gimhae, Korea)에 넣어 밀봉한 후 $10^{\circ} \mathrm{C}$ 배양 기에서 저장하면서 3 일 간격으로 총균수를 측정하였다. 측 정용 시료는 생면 $10 \mathrm{~g}$ 에 멸균 펩톤수 $90 \mathrm{~mL}$ 를 첨가하여 stomacher(LB W400, TMC, Seoul, Korea)로 1분간 균질화한 후 10 배 희석법으로 단계별로 희석한 후 pour plate method 로 측정하였으며 각 단계 희석액을 plate count agar(Difco, Becton Dickinson, Palo Alto, CA, USA)에 접종하여 $37^{\circ} \mathrm{C}$ 에 서 24시간 배양 후 나타난 colony수를 계측하였다.

\section{양파 조리면의 관능검사}

양파 조리면에 대한 관능검사는 관능검사의 경험이 있는 대구가톨릭대학교 식품공학전공 대학원생 및 학부생 15 명 을 대상으로 실시하였으며, 관능검사 실시 전 각각의 항목 에 대해 잘 인지하도록 충분히 설명한 후 실시하였다. 관능 검사용 국수는 관능검사 시작 전에 생면 $100 \mathrm{~g}$ 을 멸치 우린 물 $1 \mathrm{~L}$ 에 5 분간 저어가면서 삶은 후 종이컵에 국물과 국수 의 양을 일정하게 담아 제 공하였다. 시료번호는 난수표에 의해 3자리의 숫자로 표기하고 한 개의 시료를 평가한 후 반드시 생수로 입안을 헹구고 다른 시료를 평가하도록 하였 다. 측정 방법은 외관(appearance), 맛(taste), 냄새(flavor), 조직감(texture), 전체적인 기호도(overall acceptability)에 대하여 5점 채점법으로 실시하였으며 1점은 매우 나쁘다, 5점은 매우 좋다로 평가되었다.

\section{통계처리}

양파 생면의 조리특성 실험 $(n=9)$, 조직감 측정 $(n=10)$ 과 관능검사 $(\mathrm{n}=15)$ 를 제외하고 모든 실험은 3 회 반복으로 행 하여 평균치와 표준편차로 나타내었으며, 통계처리는 SPSS 통계 package program(statistical package social science, version 12.0)을 이용하여 분산분석(ANOVA)을 실 시하였고, 처리군 간의 유의성은 Duncan's multiple range test로 검정하여 분석 평가하였다 $(\mathrm{p}<0.05)$.

\section{결과 및 고찰}

양파 생면의 수분함량과 $\mathrm{pH}$

양파분말의 첨가량을 달리하여 제조한 생면의 수분함량 과 $\mathrm{pH}$ 를 측정한 결과는 Table 2 와 같다. 수분함량은 대조구 (OP0)가 $31.80 \%$, 양파분말 $3 \%$ 첨가구(OP3)는 $31.49 \%, 5 \%$ 첨가구(OP5)는 $30.50 \%, 10 \%$ 첨가구(OP10)는 $28.54 \%$ 로 나 타나 양파분말 첨가량이 증가함에 따라 감소하는 경향을 나타내었으나 유의적인 차이는 없었다. $\mathrm{pH}$ 는 양파분말 첨 가량이 증가할수록 감소하였는데 이는 양파분말의 $\mathrm{pH}$ 가 밀가루의 $\mathrm{pH}(5.28$ vs. 5.89; data not shown) 보다 낮기 때문 인 것으로 사료된다.

$\operatorname{Kim}$ 과 Jung(10)은 버찌분말을 1 3\% 첨가한 생면의 수분 함량을 측정한 결과, 대조구 $(33.50 \%)$ 와 버찌분말 첨가군 (33.48 33.09\%) 간에 수분함량의 차이가 없는 것으로 보고 하였으며, Jung(14)도 천년초분말 첨가(1 5\%) 국수의 수분 함량은 천년초 첨가량에 영향을 받지 않는 것으로 보고하였 는데 본 연구와 비교했을 때 첨가량은 다소 다르나 비슷한 결과를 나타내었다.

Table 2. Moisture and $\mathrm{pH}$ of raw noodles containing different concentrations of onion powder

\begin{tabular}{ccccc}
\hline \multirow{2}{*}{ Characteristic } & \multicolumn{4}{c}{ Noodle $^{1)}$} \\
\cline { 2 - 5 } & OP0 (control) & OP3 & OP5 & OP10 \\
\hline Moisture (\%) & $\left.31.80 \pm 1.77^{\mathrm{a} 2}\right)$ & $31.49 \pm 2.47^{\mathrm{a}}$ & $30.50 \pm 0.38^{\mathrm{a}}$ & $28.54 \pm 2.39^{\mathrm{a}}$ \\
$\mathrm{pH}$ & $5.84 \pm 0.02^{\mathrm{a}}$ & $5.61 \pm 0.02^{\mathrm{b}}$ & $5.52 \pm 0.16^{\mathrm{c}}$ & $5.42 \pm 0.02^{\mathrm{d}}$ \\
\hline
\end{tabular}

${ }^{1)} \mathrm{OPO}$ (control), noodle added with $0 \%$ onion powder; OP3, noodle added with $3 \%$ onion powder; OP5, noodle added with $5 \%$ onion powder; OP10, noodle added with $10 \%$ onion powder.

${ }^{2)} \mathrm{Mean} \pm \mathrm{SD}$ of triplicate determinations. Means with different superscripts within a row indicate significant differences $(p<0.05)$.

\section{양파 생면의 조리특성}

양파 생면의 조리특성을 측정한 결과(Table 3), 조리 후 중량은 대조구가 $81.11 \mathrm{~g}$, 양파분말 첨가군(OP3-OP10)이 $77.67 \sim 78.04 \mathrm{~g}$ 으로 대조구에 비해 양파분말 첨가군이 다소 낮은 값을 보였으나 유의적인 차이는 없었다. 부피와 수분 흡수율도 중량 변화와 마찬가지로 대조구와 양파분말 첨가 군 간에 유의적인 차이는 나타나지 않았는데, 이는 조리시 국수의 수분흡수율이 조리면의 중량과 부피에 영향을 미치 기 때문(3)이라 여겨진다. Lee와 Shim(7)은 국수를 삶아 조리할 때 수분의 흡수가 과다할 때는 국수가 부드러워지고 탄력성 또한 감소되어 국수의 질감을 저하시킨다고 보고하 였는데, 본 실험에서는 양파분말을 $10 \%$ 까지 첨가하여도 수분흡수율에는 영향을 미치지 않으므로 조리면의 질감에 도 영향을 미치지 않으리라 여겨진다.

$\operatorname{Kim}$ 과 $\operatorname{Shim(3)ㅇㅡㄴ~ㅇㅑㅇㅍㅏㅂㅜㄴㅁㅏㄹ(0\% ,~} 2.5 \%, 5 \%, 7.5 \%, 10 \%)$ 을 첨가하여 만든 국수의 조리특성을 살펴본 결과, 조리면의 
중량과 부피 및 수분흡수율은 $2.5 \%$ 를 첨가했을 때 가장 높게 나타나고 그 이후 첨가량이 증가함에 따라 감소되는 것으로 보고하여 본 실험의 결과와는 다소 차이가 있었는 데, 이는 국수 제조시 사용된 물의 함량 차이와 $\mathrm{Kim}$ 과 $\operatorname{Shim(3)ㅇㅡㄴ~30ㅅㅣㄱㅏㄴ~ㅈㅏㅇㅕㄴㄱㅓㄴㅈㅗ~ㅅㅣㅋㅣㄴ~ㅎㅜ~ㄱㅜㄱㅅㅜㄹㅡㄹ~ㅅㅣㄹㅎㅓㅁㅇㅔ~ㅅㅏㅇㅛㅇㅎㅏㄴ~}$ 반면 본 연구에서는 별도의 건조 과정 없이 생면을 사용하 였기 때문이라 여겨진다.

한편 본 실험에서 국물의 탁도를 나타내는 흡광도는 양 파분말 첨가군 간에는 양파분말 첨가량이 증가할수록 탁도 가 증가하는 경향이었다. 이는 국수 제조시 연근분말의 첨 가량이 많아질수록 고형분의 손실량이 커져 탁도가 높게 나타났다고 보고한 Park 등(9)의 결과와 비슷하였다. 그러 나 대조구가 양파분말 $3 \%$ 와 $5 \%$ 첨가구보다 약간 높게 나타 난 경향에 대해서는 차후 연구가 요구된다.

Table 3. Cooking characteristics of raw noodles containing different concentrations of onion powder

\begin{tabular}{|c|c|c|c|c|}
\hline \multirow[b]{2}{*}{ Characteristic } & \multicolumn{4}{|c|}{ Noodle $^{1)}$} \\
\hline & $\begin{array}{c}\mathrm{OP0} \\
\text { (control) }\end{array}$ & $\mathrm{OP} 3$ & OP5 & OP10 \\
\hline Weight (g) & $81.11 \pm 4.69^{a 22}$ & $78.04 \pm 4.61^{\mathrm{a}}$ & $77.67 \pm 3.26^{\mathrm{a}}$ & $77.82 \pm 3.68^{\mathrm{a}}$ \\
\hline Volume (mL) & $70.22 \pm 5.09^{\mathrm{a}}$ & $67.67 \pm 5.43^{\mathrm{a}}$ & $67.22 \pm 3.35^{\mathrm{a}}$ & $67.67 \pm 3.87^{\mathrm{a}}$ \\
\hline Water absorption (\%) & $58.54 \pm 10.81^{\mathrm{a}}$ & $56.08 \pm 9.22^{\mathrm{a}}$ & $55.35 \pm 6.51^{\mathrm{a}}$ & $55.65 \pm 7.35^{\mathrm{a}}$ \\
\hline $\begin{array}{l}\text { Turbidity of soup } \\
\text { (OD at } 675 \mathrm{~nm})\end{array}$ & $0.54 \pm 0.06^{\mathrm{a}}$ & $0.41 \pm 0.05^{b}$ & $0.44 \pm 0.05^{\mathrm{b}}$ & $0.51 \pm 0.11^{\mathrm{a}}$ \\
\hline \multicolumn{5}{|c|}{$\begin{array}{l}\text { 1) OP0 (control), noodle added with } 0 \% \text { onion powder; OP3, noodle added with } 3 \% \\
\text { onion powder; OP5, noodle added with } 5 \% \text { onion powder; OP10, noodle added } \\
\text { with } 10 \% \text { onion powder. }\end{array}$} \\
\hline
\end{tabular}

\section{양파 생면과 조리면의 색}

양파 생면과 조리면의 색을 측정한 결과는 Table 4와 같다. 생면의 경우, 양파분말 첨가량이 증가할수록 색의 밝은 정도를 나타내는 $\mathrm{L}$ 값과 적색도를 나타내는 $\mathrm{a}$ 값은 감 소한 반면 황색도를 나타내는 $\mathrm{b}$ 값은 증가하였으나 그 차이 가 크지 않아 육안적으로는 식별하기가 어려웠다. 조리면 의 경우, 양파분말 $10 \%$ 첨가구가 $3 \%$ 첨가구에 비해 $\mathrm{a}$ 값이 낮은 것을 제외하고는 $\mathrm{L}, \mathrm{a}, \mathrm{b}$ 값 모두 양파분말 첨가량에 따른 유의적인 차이는 나타나지 않았다.

한편 생면과 조리면의 색을 비교해 볼 때, 조리면의 $\mathrm{L}$, $\mathrm{a}, \mathrm{b}$ 값은 생면의 $\mathrm{L}, \mathrm{a}, \mathrm{b}$ 값보다 모두 낮은 값을 나타내었는데 이는 조리 시 열처리가 색의 변화에 영향을 미친 것으로 사료된다. Park 등(9)은 연근분말 첨가량을 달리하여 제조 한 건면의 색을 측정한 결과, 연근분말 첨가량이 증가할수 록 $\mathrm{L}$ 값과 $\mathrm{b}$ 값은 감소하고 $\mathrm{a}$ 값은 증가하였다고 보고하여 본 실험의 결과와는 다소 다른 경향을 나타내었는데 이는 첨가물의 종류와 첨가량에 따른 차이로 여겨진다. $\mathrm{Kim}$ 과 $\operatorname{Jung}(10)$ 은 버찌분말 첨가 국수의 조리전과 조리후의 색을
비교해 본 결과 버찌분말 첨가군의 경우 생면에 비해 조리 면에서 명도, 적색도, 황색도 모두 유의적으로 감소하였다 고 보고하였는데 이는 본 연구의 결과와 일치하였다.

Table 4. Color values of raw and cooked noodles containing different concentrations of onion powder

\begin{tabular}{cccccc}
\hline \multirow{2}{*}{ Color } & \multirow{2}{*}{ Noodle } & \multicolumn{4}{c}{ Noodle $^{1)}$} \\
\cline { 3 - 6 } & & OP0 (control) & OP3 & OP5 & OP10 \\
\hline \multirow{2}{*}{ L } & Raw & $\left.85.10 \pm 0.30^{\mathrm{a} 2}\right)$ & $84.75 \pm 0.11^{\mathrm{a}}$ & $84.35 \pm 0.25^{\mathrm{b}}$ & $83.75 \pm 0.03^{\mathrm{c}}$ \\
& Cooked & $73.74 \pm 1.22^{\mathrm{a}}$ & $73.65 \pm 3.63^{\mathrm{a}}$ & $70.92 \pm 1.28^{\mathrm{a}}$ & $72.54 \pm 2.66^{\mathrm{a}}$ \\
\hline \multirow{2}{*}{$\mathrm{a}$} & Raw & $-1.27 \pm 0.06^{\mathrm{a}}$ & $-1.98 \pm 0.05^{\mathrm{b}}$ & $-2.05 \pm 0.08^{\mathrm{bc}}$ & $-2.12 \pm 0.07^{\mathrm{c}}$ \\
& Cooked & $-2.76 \pm 0.23^{\mathrm{ab}}$ & $-2.28 \pm 0.45^{\mathrm{a}}$ & $-2.66 \pm 0.12^{\mathrm{ab}}$ & $-2.97 \pm 0.10^{\mathrm{b}}$ \\
\hline \multirow{2}{*}{$\mathrm{b}$} & Raw & $14.07 \pm 0.43^{\mathrm{c}}$ & $16.11 \pm 0.12^{\mathrm{b}}$ & $16.43 \pm 0.11^{\mathrm{b}}$ & $17.56 \pm 0.32^{\mathrm{a}}$ \\
& Cooked & $7.55 \pm 0.85^{\mathrm{a}}$ & $7.65 \pm 1.24^{\mathrm{a}}$ & $8.08 \pm 0.93^{\mathrm{a}}$ & $8.35 \pm 0.34^{\mathrm{a}}$ \\
\hline
\end{tabular}

${ }^{1)} \mathrm{OP0}$ (control), noodle added with $0 \%$ onion powder; OP3, noodle added with $3 \%$ onion powder; OP5, noodle added with $5 \%$ onion powder; OP10, noodle added with $10 \%$ onion powder.

${ }^{2)}$ Mean \pm SD of triplicate determinations. Means with different superscripts within a row indicate significant differences $(\mathrm{p}<0.05)$.

양파 생면과 조리면의 총 폴리페놀 함량과 DPPH radical 소거능

양파 생면과 조리면의 항산화성을 측정한 결과는 Table 5 와 같다. 총 폴리페놀 함량은 생면의 경우 대조군이 9.87 $\mathrm{GAE} \mathrm{mg} / \mathrm{mL}$, 양파분말을 $3 \%, 5 \%, 10 \%$ 첨가한 구는 각각 $14.33,16.89,20.62 \mathrm{GAE} \mathrm{mg} / \mathrm{mL}$ 로 양파분말 첨가량이 증가 함에 따라 증가하였으며, 조리후에도 생면에서와 같이 동 일한 경향을 나타내었으나 생면에 비해 함량은 전체적으로 감소하였다. 식품에 존재하는 polyphenol 화합물들은 우수 한 항산화력을 가지는 것으로 알려져 있으며 이는 free radical를 안정화시킬 수 있는 aromatic phenolic ring의 존재 때문인 것으로 보고되고 있다(15).

DPPH radical 소거능은 생면의 경우 대조군이 $9.86 \%$,

Table 5. Total polyphenol contents and DPPH radical scavenging activities of raw and cooked noodles containing different concentrations of onion powder

\begin{tabular}{|c|c|c|c|c|c|}
\hline \multirow[b]{2}{*}{ Value } & \multirow[b]{2}{*}{ Noodle } & \multicolumn{4}{|c|}{ Noodle $^{1)}$} \\
\hline & & $\begin{array}{c}\mathrm{OP0} \\
\text { (control) }\end{array}$ & $\mathrm{OP} 3$ & OP5 & OP10 \\
\hline Polyphenol & Raw & $9.87 \pm 0.18^{(2)}$ & $14.33 \pm 0.24^{c}$ & $16.89 \pm 0.34^{b}$ & $20.62 \pm 0.35^{\mathrm{a}}$ \\
\hline (mg GAE/mL) & Cooked & $5.59 \pm 0.46^{\mathrm{d}}$ & $9.65 \pm 0.16^{c}$ & $11.62 \pm 0.16^{b}$ & $15.59 \pm 0.66^{\mathrm{a}}$ \\
\hline DPPH & Raw & $9.86 \pm 1.06^{\mathrm{d}}$ & $20.50 \pm 3.68^{c}$ & $29.22 \pm 1.86^{b}$ & $40.12 \pm 0.53^{\mathrm{a}}$ \\
\hline (\%) & Cooked & $7.09 \pm 0.46^{d}$ & $11.14 \pm 1.41^{c}$ & $14.61 \pm 0.35^{\mathrm{b}}$ & $21.53 \pm 0.52^{\mathrm{a}}$ \\
\hline
\end{tabular}

${ }^{1)} \mathrm{OPO}$ (control), noodle added with $0 \%$ onion powder; OP3, noodle added with $3 \%$ onion powder; OP5, noodle added with $5 \%$ onion powder; OP10, noodle added with $10 \%$ onion powder.

${ }^{2)}$ Mean \pm SD of triplicate determinations. Means with different superscripts within a row indicate significant differences $(\mathrm{p}<0.05)$. 
양파분말을 $3 \%, 5 \%, 10 \%$ 첨가한 구는 각각 $20.50 \%$, $29.22 \%, 40.12 \%$ 로 나타나 양파분말 첨가량이 증가함에 따 라 증가하였으며, 조리후에도 생면에서와 같이 동일한 경 향을 나타내었으나 생면에 비해 소거능은 전체적으로 감소 하였다. Kim 등(16)은 DPPH 라디칼 소거능은 총 폴리페놀 함량이 높을수록 높게 나타난다고 보고하였는데 이는 본 실험의 결과와 일치하였다.

\section{양파 조리면의 조직감}

양파 조리면의 조직감을 측정한 결과(Table 6), 경도 (hardness)와 씹힘성(chewiness)은 대조구가 양파분말 첨가 군에 비해 높게 나타났으며 양파분말 첨가군 간에는 유의적 인 차이는 없었다. 응집성(cohesiveness)은 양파분말 $5 \%$ 첨 가구가 가장 높은 값을 나타내는 경향이었으며 탄력성 (springiness)은 대조구와 양파분말 첨가군 간에 유의적인 차이는 없었다.

$\operatorname{Kim}$ and $\operatorname{Shim}(3)$ 은 양파분말(0\%, $2.5 \%, 5 \%, 7.5 \%, 10 \%)$ 을 첨가한 조리면의 조직감을 측정한 결과, 경도와 씹힘성 은 대조구가 가장 낮은 값을 나타내었으나 이후 양파분말 첨가량의 증가에 따라 일정한 증감 현상은 나타나지 않았으 며 응집성과 탄력성은 대조구와 양파분말 첨가군 간에 유의 적인 차이가 없었다고 보고하였다. 한편 Lee와 Shim(7)은 양파즙 $(0 \%, 25 \%, 50 \%, 75 \%, 100 \%)$ 을 첨가한 조리면의 조 직감 측정에서 경도는 대조구가 가장 높았으나 양파즙의 함량이 증가함에 따라 유의적으로 감소하였으며, 씹힘성은 양파즙 함량이 $25 \%$ 일 때 가장 높은 값을 보였고 탄력성은 대조구와 양파즙 첨가군 간에 유의적인 차이가 없었다고 보고하였다. 상기 실험결과는 본 연구의 결과와 다소 차이 가 있었는데 이는 생면과 조리면의 제조방법 및 조직감 측정조건 등의 차이에서 기인하리라 여겨진다.

Table 6. Textural characteristics of cooked noodles containing different concentrations of onion powder

\begin{tabular}{ccccc}
\hline \multirow{2}{*}{ Texture } & \multicolumn{4}{c}{ Noodle $^{\mathrm{l})}$} \\
\cline { 2 - 5 } & OP0 (control) & OP3 & OP5 & OP10 \\
\hline Hardness $\left(\mathrm{g} / \mathrm{cm}^{2}\right)$ & $1338.70 \pm 199.01^{\mathrm{a} 2)}$ & $1000.40 \pm 169.00^{\mathrm{b}}$ & $860.35 \pm 233.75^{\mathrm{b}}$ & $878.85 \pm 103.66^{\mathrm{b}}$ \\
Cohesiveness (\%) & $72.93 \pm 4.71^{\mathrm{b}}$ & $74.74 \pm 3.09^{\mathrm{ab}}$ & $76.77 \pm 3.17^{\mathrm{a}}$ & $72.66 \pm 2.73^{\mathrm{b}}$ \\
Chewiness (\%) & $1209.34 \pm 180.06^{\mathrm{a}}$ & $939.15 \pm 168.50^{\mathrm{b}}$ & $827.17 \pm 242.46^{\mathrm{b}}$ & $825.14 \pm 103.72^{\mathrm{b}}$ \\
Springiness (\%) & $90.24 \pm 5.77^{\mathrm{a}}$ & $90.54 \pm 3.04^{\mathrm{a}}$ & $85.18 \pm 9.28^{\mathrm{a}}$ & $88.60 \pm 1.98^{\mathrm{a}}$ \\
\hline
\end{tabular}

${ }^{1)} \mathrm{OPO}$ (control), noodle added with $0 \%$ onion powder; OP3, noodle added with $3 \%$ onion powder; OP5, noodle added with $5 \%$ onion powder; OP10, noodle added with $10 \%$ onion powder.

${ }^{2)}$ Mean \pm SD of ten measurements. Means with different superscripts within a row indicate significant differences $(p<0.05)$.

\section{양파 생면의 저장성}

양파 생면을 $10^{\circ} \mathrm{C}$ 에서 12 일간 저장하면서 3 일 간격으로 총균수를 측정한 결과는 Table 7과 같다. 저장초기에 양파
분말을 첨가하지 않은 대조구의 총균수는 $3.17 \log \mathrm{CFU} / \mathrm{g}$, 양파분말 $3 \%, 5 \%, 10 \%$ 첨가구의 총균수는 각각 $2.35,2.20$, $1.94 \log \mathrm{CFU} / \mathrm{g}$ 으로 나타나 양파분말 첨가량이 증가할수록 초기 총균수는 낮게 나타났다. 이러한 양파분말 첨가량의 증가에 따른 총균수의 감소 현상은 저장 12 일째까지 나타 났는데, 저장 12 일째 대조구는 $8.54 \log \mathrm{CFU} / \mathrm{g}$, 양파분말 $3 \%, 5 \%, 10 \%$ 첨가구는 각각 $5.98,4.27,4.00 \log \mathrm{CFU} / \mathrm{g}$ 의 총균수를 나타내었다.

Table 7. Changes in total viable cells (log CFU/g) of raw noodles containing different concentrations of onion powder during storage at $10^{\circ} \mathrm{C}$ for 12 days

\begin{tabular}{ccccc}
\hline \multirow{2}{*}{$\begin{array}{c}\text { Storage time } \\
\text { (days) }\end{array}$} & \multicolumn{4}{c}{ Noodle $^{1)}$} \\
\cline { 2 - 5 } & OP0 (control) & OP3 & OP5 & OP10 \\
\hline 0 & $3.17 \pm 0.01^{\mathrm{a} 2)}$ & $2.35 \pm 0.05^{\mathrm{b}}$ & $2.20 \pm 0.00^{\mathrm{c}}$ & $1.94 \pm 0.04^{\mathrm{d}}$ \\
3 & $3.42 \pm 0.08^{\mathrm{a}}$ & $2.48 \pm 0.00^{\mathrm{c}}$ & $2.72 \pm 0.02^{\mathrm{b}}$ & $2.22 \pm 0.07^{\mathrm{d}}$ \\
6 & $7.11 \pm 0.00^{\mathrm{a}}$ & $3.97 \pm 0.01^{\mathrm{b}}$ & $3.27 \pm 0.01^{\mathrm{c}}$ & $3.14 \pm 0.13^{\mathrm{d}}$ \\
9 & $8.13 \pm 0.02^{\mathrm{a}}$ & $4.99 \pm 0.00^{\mathrm{b}}$ & $3.61 \pm 0.00^{\mathrm{c}}$ & $3.45 \pm 0.01^{\mathrm{d}}$ \\
12 & $8.54 \pm 0.02^{\mathrm{a}}$ & $5.98 \pm 0.03^{\mathrm{b}}$ & $4.27 \pm 0.01^{\mathrm{c}}$ & $4.00 \pm 0.03^{\mathrm{d}}$ \\
\hline
\end{tabular}

${ }^{1)} \mathrm{OPO}$ (control), noodle added with $0 \%$ onion powder; OP3, noodle added with $3 \%$ onion powder; OP5, noodle added with $5 \%$ onion powder; OP10, noodle added with $10 \%$ onion powder.

${ }^{2)}$ Mean \pm SD of triplicate determinations. Means with different superscripts within a row indicate significant differences $(\mathrm{p}<0.05)$.

현행 우리나라의 식품공전(Food Code)(17)에 따르면 생 면에서 세균수의 최대 허용치는 $3.0 \times 10^{6} \mathrm{CFU} / \mathrm{g}=6.48 \mathrm{log}$ $\mathrm{CFU} / \mathrm{g}$ ) 이하로 되어 있으며, 생면은 수분함량이 높은 상태 에서 유통되기 때문에 저장성이 낮아 유통기한이 실온에서 는 2 일, 냉장시에는 7 일로 권장되고 있다. 본 연구에서는 대조구의 경우 저장 6일째 총균수가 $7.11 \log \mathrm{CFU} / \mathrm{g}$ 을 나타 내어 식품공전에서 설정한 총균수 기준치인 $6.48 \log \mathrm{CFU} / \mathrm{g}$ 을 초과하였다. 반면 양파분말 $3 \%, 5 \%, 10 \%$ 첨가군은 저장 12 일째에도 식품공전에서 설정한 총균수 기준치에 미달하 였다. 이상의 결과로 볼 때 양파분말을 $3 \%$ 이상 첨가시 생면의 저장성은 대조구에 비하여 최소 6 일 이상 연장시킬 수 있을 것으로 판단된다. 양파분말 첨가량에 따른 세균증 식 억제 효과를 비교해 보면, 저장 9 일째와 12 일째 양파분말 $5 \%$ 첨가구는 양파분말 $3 \%$ 첨가구에 비해 $1 \log$ cycle 이상 세균증식 억제효과가 나타났으나 양파분말 $10 \%$ 첨가구는 양파분말 $5 \%$ 첨가구에 비해 $0.5 \log$ cycle 미만의 세균증식 억제효과를 나타내어 양파분말 $5 \%$ 첨가가 생면의 저장성 연장 측면에서 가장 효과적인 것으로 사료되었다.

지금까지 천연물을 첨가한 생면의 저장성 연구에 의하 면, 천년초분말(14)과 버찌분말(10) 등의 첨가가 생면의 세 균증식 억제에 효과가 있음이 보고되어 앞으로 천연물을 첨가한 생면의 저장성 연장에 관한 폭 넓은 연구가 기대된 다. 
양파 조리면의 관능검사

양파분말의 첨가량을 달리하여 제조한 국수를 삶은 후 관능검사를 실시한 결과(Table 8), 국수의 외관, 맛, 냄새, 조직감 및 전체적인 기호도는 대조구와 양말분말 첨가군 간에 모두 유의적인 차이를 나타내지 않았다. 따라서 본 관능검사 결과로 볼 때 양파분말을 첨가하여 국수를 제조시 양파분말의 첨가량에 따른 맛이나 냄새로 인한 부정적인 영향은 보여지지 않았는데 이는 양파분말을 첨가한 기능성 국수의 개발 가능성을 시사하고 있다. Shin 등(8)도 양파즙 을 첨가한 양파생면에 대한 소비자 기호도 조사에서 양파생 면이 상품으로서 개발 가능성을 확인한 바 있다.

Table 8. Sensory quality of cooked noodles containing different concentrations of onion powder

\begin{tabular}{ccccc}
\hline \multirow{2}{*}{ Attribute } & \multicolumn{4}{c}{ Noodle $^{1)}$} \\
\cline { 2 - 5 } & OP0 (control) & OP3 & OP5 & OP10 \\
\hline Appearance & $3.53 \pm 1.12^{\mathrm{a} 2)}$ & $3.67 \pm 0.90^{\mathrm{a}}$ & $3.93 \pm 1.10^{\mathrm{a}}$ & $3.47 \pm 1.12^{\mathrm{a}}$ \\
Taste & $3.20 \pm 0.68^{\mathrm{a}}$ & $3.13 \pm 1.12^{\mathrm{a}}$ & $3.47 \pm 1.12^{\mathrm{a}}$ & $3.00 \pm 1.36^{\mathrm{a}}$ \\
Flavor & $2.87 \pm 0.91^{\mathrm{a}}$ & $3.20 \pm 0.77^{\mathrm{a}}$ & $3.33 \pm 0.90^{\mathrm{a}}$ & $3.13 \pm 0.99^{\mathrm{a}}$ \\
Texture & $3.20 \pm 1.01^{\mathrm{a}}$ & $3.53 \pm 0.64^{\mathrm{a}}$ & $3.47 \pm 0.74^{\mathrm{a}}$ & $3.07 \pm 0.70^{\mathrm{a}}$ \\
Overall acceptability & $2.93 \pm 0.80^{\mathrm{a}}$ & $3.40 \pm 0.74^{\mathrm{a}}$ & $3.27 \pm 0.96^{\mathrm{a}}$ & $3.13 \pm 1.12^{\mathrm{a}}$ \\
\hline
\end{tabular}

${ }^{1)} \mathrm{OP} 0$ (control), noodle added with $0 \%$ onion powder; OP3, noodle added with $3 \%$ onion powder; OP5, noodle added with $5 \%$ onion powder; OP10, noodle added with $10 \%$ onion powder.

${ }^{2)} \mathrm{Mean} \pm \mathrm{SD}$ of 15 panelists. Means with different superscripts within a row indicate significant differences $(\mathrm{p}<0.05)$.

\section{요 약}

본 연구에서는 기능성 부여와 저장성이 증진된 국수를 개발하고자 양파분말을 국수에 첨가 $(0,3,5,10 \%)$ 한 후 품질특성과 저장성을 조사하였다. 양파 생면의 수분은 양 파분말 첨가량의 증가에 따른 차이는 없었으나 $\mathrm{pH}$ 는 감소 하였다. 양파 생면의 조리 후 중량과 부피, 수분흡수율은 대조구와 양파분말 첨가군 간에 차이가 없었다. 색의 경우 생면은 양파분말 첨가량이 증가할수록 $\mathrm{L}$ 값과 $\mathrm{a}$ 값은 감소하 고 $\mathrm{b}$ 값은 증가하였으나 조리면은 큰 차이를 나타내지 않았 다. 생면의 총 폴리페놀 함량과 DPPH radical 소거능은 양파 분말 첨가량이 증가함에 따라 증가하였으며 조리후에는 함량이 전체적으로 감소하였으나 생면과 동일한 경향을 나타내었다. 양파 조리면의 조직감의 경우, 경도와 씹힘성 은 대조구가 양파 첨가군에 비해 높게 나타났으나 탄력성은 대조구와 양파분말 첨가군 간에 차이가 없었다. 생면을 1 $0^{\circ} \mathrm{C}$ 에서 12 일간 저장하면서 총균수를 측정한 결과 양파분 말 첨가군은 대조구에 비하여 저장성이 최소 6 일 이상 연장 될 수 있었으며 그 중 양파분말 5\% 첨가구가 가장 효과적인 것으로 간주되었다. 양파 조리면의 관능검사 결과 외관,
맛, 냄새, 조직감 및 전체적인 기호도는 대조구와 양말분말 첨가군 간에 차이가 없었다. 따라서 본 연구결과로 볼 때 양파분말을 국수에 $5 \%$ 첨가함으로서 기능성 부여와 저장 성이 증진된 국수를 개발할 수 있으리라 생각된다.

\section{References}

1. Park HJ, Yu IS, Kim SK, Lee YS, Kim YB (1994) Prediction of shelf-life of noodles by bacterial count. Korean J Food Sci Technol, 26, 557-560

2. Kim JS, Son JY (2004) Effects of condensed phosphates on the quality and shelf-life of wet noodle. Korean J Food Cookery Sci, 20, 133-137

3. Kim JG, Shim JY (2006) Quality characteristics of wheat flour noodle added with onion powder. Food Eng Progress, 10, 269-274

4. Hwang IG, Kim HY, Lee SH, Hwang CR, Oh SH, Woo KS, Kim DJ, Lee JS, Jeong HS (2011) Isolation and identification of an antioxidant substance from heated onion (Allium cepa L.). J Korean Soc Food Sci Nutr, 40, 470-474

5. Kwak HJ, Kwon YJ, Jeong PH, Kwon JH, Kim HK (2000) Physiological activity and antioxidative effect of methanol extract from onion (Allium cepa L.). J Korean Soc Food Sci Nutr, 29, 349-355

6. Chung DO, Park ID, Jung HO (2001) Evaluation of functional properties of onion, rosemary, and thyme extracts in onion kimchi. Korean J Soc Food Cookery Sci, 17, 218-223

7. Lee JH, Shim JY (2006) Characteristics of wheat flour dough and noodles added with onion juice. Food Eng Progress, 10, 54-59

8. Shin WS, Shin ES, Lyu ES (2009) Optimization of wet noodle with onion juice using response surface methodology. Korean J Food Cookery Sci, 25, 31-38

9. Park BH, Cho HS, Bae KY (2008) Quality characteristics of dried noodle made with Lotus root powder. Korean J Food Cookery Sci, 24, 593-600

10. Kim SH, Jung BM (2013) Quality characteristics of noodles containing various levels of flowering cherry (Prunus serrulata L. var. spontanea Max. wils.) fruit powder. Korean J Food Cookery Sci, 29, 19-28

11. Folin O, Denis W (1912) On phosphotungsticphosphomolybdic compounds as color reagents. J Biol Chem, 12, 239-243

12. Blois MS (1958) Antioxidant determinations by the use 
of a stable free radical. Nature, 181, 1199-1200

13. Park JH, Ko SH, Yoo SS (2010) Quality characteristics of wet noodles added with freeze-dried maesangi powder. Korean J Food Cookery Sci, 26, 831-839

14. Jung BM (2010) Quality characteristics and storage properties of wet noodle with added cheonnyuncho fruit powder. Korean J Food Cookery Sci, 26, 821-830

15. Rice-Evans C, Miller N, Paganga G (1997) Antioxidant properties of phenolic compounds. Trends Plant Sci, 2, 152-159

16. Kim HK, Kim YE, Do JR, Lee YC, Lee BY (1995) Antioxidative activity and physiological activity of some Korean medical plants. Korean J Food Sci Technol, 27, 80-85

17. Food Code (1997) Ministry of Health and Welfare, Seoul, Korea, p 295-298 